\title{
Atando a Gulliver: los Estados débiles del mundo islámico frente a la expansión hegemónica norteamericana
}

\author{
Tying Gulliver down: Islamic world's weak states \\ in the face of American hegemonic expansion
}

\author{
Luis L. Schenoni*
}

\section{Resumen}

El presente trabajo intenta describir el comportamiento de los Estados débiles frente a un contexto de expansión hegemónica, partiendo de la base de que el período comprendido entre el desmembramiento de la Unión Soviética y la invasión de Irak durante el año 2003 fue un momento de vacío de poder y expansión norteamericana hacia distintas regiones del globo, especialmente el Medio Oriente. Se analiza la reacción de un grupo de Estados del mundo islámico (Afganistán, Irak, Irán, Libia y Paquistán) a las políticas gestadas desde Washington para la región, intentando deducir un patrón que describa parsimoniosamente las variables principales de dicha interacción, cuáles fueron las fronteras impuestas a la soberanía de esos Estados y cuáles los límites que pudieron imponer al expansionismo norteamericano en su región. Para ello, se intentará comparar las respuestas que las distintas escuelas de pensamiento de la teoría de las relaciones internacionales darían a

Profesor del Instituto de Ciencias Políticas y Relaciones Internacionales, Universidad Católica Argentina.

Recibido 11 de diciembre de 2009, aceptado el 15 de junio de 2010. 
nuestro interrogante. Luego de rescatar del olvido académico los escritos teóricos dedicados al análisis de los Estados débiles, se desarrollará con mayor detenimiento el planteo de la escuela realista, introduciendo un modelo de interacción basado en sus axiomas fundamentales.

Palabras Clave: teoría de las relaciones internacionales, Estados débiles, Afganistán, Irak

\section{Abstract}

This article intends to describe the behaviour of weak states within a context of hegemonic expansion, assuming that, from the crisis and fall of the Soviet Union to the beginning of the Irak War, this is the situation that best describes American offensive policies toward power vacuum situations in regions such as the Middle East. Therefore, the reaction of a representative sample of states in that region (Afghanistan, Iraq, Iran, Libya and Pakistan) will be analyzed in accordance with policies designed in Washington, trying to describe the most important variables of the interaction as well as restraints imposed to sovereignty of these states and the limits to American expansionism in this region. In order to deal with this matter, a discussion on the different responses given by the international relations theories will be intended. After rescuing theoretical thought on weak states from oblivion, we will try to develop an explanation based on a new model of interaction based on realistic premises.

KeY wORDs: international relations theory, weak states, Afghanistan, Iraq. 
Luis L. SCHENONI • Atando a Gulliver: los Estados débiles del mundo islámico...

\section{INTRODUCCIÓN}

Durante la primera década del siglo XXI han corrido ríos de tinta dedicados a criticar la decisión norteamericana de invadir Afganistán y en mayor medida, Irak. Por lo general, el análisis de estos fenómenos se ha centrado en la política exterior de las administraciones de George W. Bush, interpretándola como una aplicación ideologizada de lo que algunos intelectuales «neoconservadores» defendían como el justo rol que le correspondía desempeñar a los Estados Unidos post 11-S en un mundo que creían sin competidores dignos. Sin embargo, la literatura producida hasta hoy termina por reducir la explicación de estos fenómenos a un mero estado de ánimo intelectual en Washington, pues aunque compartamos la hipótesis sistémica de la fatalidad de una sobreexpansión de los Estados Unidos post $11-S$, cabe preguntarse por qué no se produjo durante la primera década del momento unipolar y por qué Afganistán e Irak la sufrieron en el marco de una lucha global contra el terrorismo. A medida que el tiempo pasa, la academia se enfrenta al imperativo de dar una explicación racional a estos sucesos, dejando de lado la literatura fundamentalmente periodística de los últimos años.

El presente trabajo no aspira a resolver el problema de las causas de estas invasiones, temática destinada a ser objeto de trabajos mucho más ambiciosos. Sin embargo, intentará explicar qué factores determinaron que la expansión norteamericana afectara a Afganistán e Irak y no a otros Estados en condiciones similares. Esta última cuestión adquiere especial interés si nos percatamos de que muchos de los Estados del mundo musulmán están fuertemente influenciados por el fundamentalismo islámico, poseen regímenes políticos autoritarios o iliberales, se sospecha que poseen armas de destrucción masiva y ostentan reservas petroleras -entendiendo que estos son los principales móviles, declarados o supuestos, de las invasiones-. Preguntarse por qué fueron invadidos Afganistán e Irak en lugar de muchos otros Estados que comparten estas características -Irán, Libia, Paquistán, Siria y Sudán, entre otros- puede ser importante para echar luz sobre las verdaderas causas de este fenómeno. El trabajo se centrará en la diplomacia de estos países y se preguntará qué políticas adoptaron los Estados del mundo musulmán para asegurar su supervivencia en el marco de la «lucha contra el terrorismo» o, puesto de otro modo, qué errores u omisiones de los gobiernos de Afganistán e Irak convirtieron a estos dos países en blancos de la fatal sobre-expansión norteamericana.

Para contestar la pregunta nos enmarcaremos en la bibliografía de las relaciones internacionales que trata de las posibilidades que tienen los Estados débiles de salvaguardar su supervivencia y mejorar su condición relativa en el sistema internacional. Paralelamente, recurriremos a un acotado estudio comparado de casos -Afganistán, Irak, Irán, Libia y Paquistán, desde 1989 a 
2004- con el fin de contrastar las acciones y omisiones de los perdedores y los ganadores de este juego, verificando, llegado el caso, que los Estados débiles que actuaron de acuerdo con las prescripciones del paradigma realista lograron salir airosos de esta coyuntura. Para reforzar esta visión construiremos $\mathrm{y}$ aplicaremos un modelo que intentará reflejar la concepción realista de los Estados débiles en un contexto de expansión hegemónica hacia su región. De comprobarse nuestra hipótesis, los Estados débiles del mundo musulmán que siguieron este paradigma habrían podido imponer un freno realista a la política neoconservadora de los Estados Unidos.

\section{Los Estados dÉbILES EN LA TEORÍA DE LAS RELACIONES INTERNACIONALES}

...el derecho, tal como está el mundo, unicamente se discute entre quienes ostentan el poder, mientras que los

fuertes hacen lo que pueden y los débiles sufren lo que deben. Tucídides

Los ataques a Afganistán e Irak, abriendo el primer capítulo de la historia militar del siglo XXI, no son más que otro ejemplo de la utilidad de la Realpolitik para comprender la política internacional. El axioma fundacional de la tradición realista es simple: el fuerte escribe la historia a costa del débil. Sin embargo, tomar literalmente el juicio de Tucídides puede inducirnos a pensar a los Estados débiles como en una tragedia griega en la que todos los esfuerzos por modificar su destino serían inútiles. Es cierto que la primacía teórica del realismo ha llevado al olvido de los Estados débiles -al fin y al cabo, la historia la escriben los fuertes-, pero en rigor, esta visión fatalista no ha sido compartida por gran parte de la literatura, incluso realista, dedicada a estos actores secundarios.

El pensamiento reciente sobre los Estados débiles -también llamados pequeños o periféricos, según el contexto- se ha desarrollado como un subconjunto de prácticamente todas las teorías generales más importantes de las relaciones internacionales. Cada una de ellas intenta hacer referencia a la situación de los Estados más pequeños, definir sus características, sus comportamientos y su margen de acción, llegando en muchos casos a desarrollar algunos consejos normativos y hasta programáticos.

Estas teorías han tenido especial impulso en el período que recorre las tres primeras décadas de la Guerra Fría, posiblemente incentivadas por el surgimiento de la representación universal en el sistema de las Naciones Unidas, el proceso de descolonización y la creación del Movimiento de Países No Alineados, entre otras coyunturas que agregaron un aliciente especial al estudio de estos actores. Algunos aseguraron por entonces que había llegado «el día de los pequeños Estados» (Vandenbosch 1964: 308). A este período no solo pertenecen los primeros 
Luis L. SCHENONI • Atando a Gulliver: los Estados débiles del mundo islámico...

libros sobre la materia (Vital 1967; Rothstein 1968), sino incluso aquellos trabajos que han sentado un precedente obligatorio para futuros análisis del comportamiento de este tipo de Estados y que desarrollan a su vez los enfoques que las distintas grandes teorías de las relaciones internacionales tienen sobre el tema (Keohane 1969; Handel 1981).

Sin embargo, el estudio del comportamiento de los Estados débiles ha caído en el olvido durante las últimas décadas, en las cuales el espectacular desenlace de la Guerra Fría y el surgimiento de un mundo unipolar han desviado la atención de los grandes teóricos de las relaciones internacionales ${ }^{1}$. Quizás

1 El debate sobre el rol de los Estados débiles, por ser de especial interés para el tercer mundo, ha sido más constante en la academia de algunos países periféricos. Aunque no se tendrán en cuenta en el presente trabajo, es menester mencionar que los avances más prolíficos han tenido lugar en Latinoamérica y pueden encontrarse dentro de las más dispares teorías.

Durante los años sesenta y setenta el principal marco para el estudio de la temática se encontró en la teoría de la dependencia, que postulaba la fatalidad de la situación periférica de los Estados débiles como una característica estructural del sistema (Cardoso y Faletto 1969). Desde finales del decenio de 1970, una nueva corriente que abrevaba en las mismas aguas del pensamiento cepaliano tomó cierta distancia de estos postulados para enfatizar la posibilidad de que los Estados débiles transitaran lentamente hacia mayores estadios de autonomía (Jaguaribe 1979; Puig 1980). Luego de terminada la Guerra Fría, el autor del mayor giro teórico fue seguramente Carlos Escudé (1995) con los postulados del por ello, la más reciente publicación al respecto (Ingebritsen 2006) no ha podido pasar de ser una compilación de algunos textos importantes sobre la materia, en su mayoría escritos más de veinte años atrás.

Esta situación deja una importante laguna en lo que respecta al análisis teórico del comportamiento de los Estados débiles en un mundo unipolar. Sin embargo, los postulados de las teorías más importantes se han establecido con la suficiente claridad -ya sea en aquellos escritos generales o en estudios de caso más contemporáneos- como para adaptar los postulados de antaño a la situación mundial de la post-Guerra Fría, marco temporal del presente trabajo.

\section{LA TEORÍA REALISTA Y OTROS ENFOQUES ALTERNATIVOS}

Adoptar el enfoque neorrealista para el análisis de la temática que nos convoca es, por lo menos, contraintuitivo. Para Waltz y sus discípulos, el sistema internacional posee naturalmente una multiplicidad de actores pero solo

llamado «realismo periférico», que enfatizaba los beneficios del alineamiento con Estados Unidos en un mundo unipolar.

Sin embargo estos desarrollos teóricos, a diferencia de los europeos y en especial de los norteamericanos, no han aspirado a constituirse en teorías generales sino más bien han intentado explicar la situación de América Latina en particular e influir en el diseño de la política exterior de sus determinados países, por lo que no se ajustan adecuadamente al marco espacial de este trabajo. 
los más importantes configuran la estructura del sistema internacional a partir de sus capacidades materiales y alianzas. Entre todos los Estados solo unos pocos resultan más capaces y la mayoría debe ajustar su conducta a esta natural distribución oligárquica del poder. Es en última instancia el orden establecido por los grandes actores lo que permite comprender y estudiar las relaciones internacionales (Waltz 1992: 132-156 y 195).

A continuación intentaremos rescatar el valor de los Estados débiles sin escapar al paradigma neorrealista. Pero para esto debemos comenzar por definir qué hace a un Estado "pequeño» en relación con las medianas o grandes potencias. En una primera aproximación al tipo ideal del Estado débil, este debería ser territorial y demográficamente pequeño, tener un bajo producto económico relativo, escaso grado de industrialización, alta dependencia del comercio exterior, débil potencial bélico, intereses limitados en el sistema internacional y comportamiento pasivo y reactivo en lo que respecta a su política exterior.

Según Michael Handel (1981), principal teórico realista de los Estados débiles, esta caracterización no siempre puede aplicarse fácilmente. Existirán Estados pequeños con alto producto económico relativo -como Suiza, Bélgica o Dinamarca-, Estados pequeños con grandes territorios y recursos -como Argentina, Kazajstán o la República Democrática del Congo- o Estados pequeños altamente poblados -como
Bangladesh o Paquistán-. Sin embargo, es interesante notar que todos comparten la característica fundamental de ser consumidores antes que productores de seguridad en el sistema internacional. Esta evidencia empírica lleva a afirmar que en última instancia «los estados débiles se caracterizan por su debilidad militar» (Handel 1981: 36).

Un Estado tal solo tiene dos caminos para incrementar su seguridad y mejorar su situación en la distribución estructural de capacidades. En principio, puede desarrollar sus capacidades explotando sus fuentes de fuerza internas, o puede acudir a fuentes de fuerza externas alineándose con una de las grandes potencias o coaliciones que equilibran el sistema. Estas dos alternativas son en última instancia las únicas que un Estado tiene para modificar y eventualmente mejorar su condición relativa en la estructura de poder. Estos conceptos son fundamentales en el neorrealismo; según este autor «una de las mayores diferencias entre un estado débil y una gran potencia es la combinación relativa de estas dos fuentes disponibles de fuerza (...) se sigue entonces que en la mayoría de los casos las fuentes externas de fuerza son más cruciales para los estados débiles y constituyen una parte relativamente mayor de su fuerza total» (Handel 1981: 69 $)^{2}$.

2 Por más que el Estado débil tenga cierta tendencia a consumir más seguridad de la que produce, existen al menos dos razones por las cuales también pretenderá desarrollar sus capacidades propias: «En pri- 
Luis L. SCHENONI • Atando a Gulliver: los Estados débiles del mundo islámico...

La simplicidad teórica del paradigma neorrealista ha dado lugar a múltiples críticas provenientes de distintos enfoques teóricos. La más influyente proviene del liberalismo y se basa en dos argumentos principales. En primer lugar, desde una perspectiva liberal, las acciones de los Estados débiles no pueden explicarse únicamente desde el nivel sistémico, sino fundamentalmente desde un nivel interno, que en este tipo de Estados es mucho más determinante (Elman 1995).

En segundo lugar, los Estados débiles no podrían mejorar su situación por medios realistas, es decir, incrementando sus capacidades y optimizando sus relaciones estratégicas. En el mismo esquema neorrealista estos dos elementos se comportan como bienes sustitutos y por lo tanto, el incremento de las capacidades militares deberá acompañarse indefectiblemente de una mengua de los beneficios derivados de las relaciones estratégicas -o viceversa-, constituyendo un juego de suma cero en el que los Estados, por mucho que se empeñen en tener más armas y amigos, como en el mito de Sísifo, nunca podrán alcanzarlo (Conybeare 1994). Según la corriente liberal -y otros enfoques como el de la escuela inglesa-, la vía por la cual

mer lugar un estado débil necesita resistir lo suficiente como para prevenir una rápida derrota o al menos el tiempo necesario para obtener la ayuda de terceros estados. La segunda razón y más interesante, es que mediante el desarrollo de poder militar, un estado débil puede impedir el ataque de estados más fuertes que él» (Handel 1981: 92). los Estados débiles pueden mejorar su condición relativa es la utilización de las instituciones internacionales. En espacios como los generados por las organizaciones multilaterales, las normas ayudan a que algunas veces una mayoría débil pueda imponerse sobre una minoría más fuerte. Solo por citar dos conocidos ejemplos: «la regla de un estado un voto del sistema de Naciones Unidas favorece las coaliciones de los pequeños y menos poderosos (...) [e incluso] los organismos internacionales también permiten que los países pequeños y débiles lleven a cabo estrategias de vinculación de cuestiones» (Keohane y Nye 1998: 55).

Es muy probable que ambos enfoques expliquen con éxito distintas situaciones en contextos diferentes. Sin embargo, nos limitaremos a demostrar a continuación cómo llegado el momento crítico de la ofensiva de Washington contra el mundo musulmán después del 11-S, resultó más efectivo el comportamiento de los Estados débiles que consciente o inconscientemente siguieron los preceptos del paradigma realista ${ }^{3}$.

3 No hemos sido en esta sección de ningún modo exhaustivos en la descripción de las teorías sobre los Estados débiles. Debemos subrayar que existe también una gran literatura que se concentra en postulados directamente «críticos» del sistema internacional, especialmente provenientes del marxismo y del constructivismo como grand theories de las relaciones internacionales. De cualquier modo, se han expuesto aquellos postulados que a juicio del autor cuentan con mayor aceptación en la academia contemporánea. 


\section{LA PERSPECTIVA DEL PEQUEÑO}

\section{Y LA PERSPECTIVA DEL GIGANTE}

Como ya se señaló, no pretendemos explicar exhaustivamente las causas de las invasiones a Afganistán e Irak a partir del estudio de los pequeños Estados del mundo islámico. Es evidente que la relevancia de la política exterior norteamericana es mucho mayor a los fines de explicar el fenómeno que la de cualquier Estado débil de la región. Es por este motivo que, aunque no sea el objeto del presente trabajo, dedicaremos algunas líneas a repasar las variables a través de las cuales los autores han intentado explicar las ofensivas militares de los Estados Unidos a principios del siglo XXI. Dentro de las explicaciones dadas al avance norteamericano sobre el Medio Oriente y Asia Central podemos discernir tres grandes líneas interpretativas: una geoestratégica, una de carácter interno y una ideológica, que fueron utilizadas separadamente o de forma combinada para explicar las causas de las invasiones ${ }^{4}$.

Los partidarios de la interpretación geoestratégica suelen poner especial énfasis en la necesidad de los Estados Unidos de abastecerse de recursos naturales escasos, así como en la importancia de situarse en territorios estratégicamente relevantes para el control militar de la región. Esta explicación, que encuentra a sus más enconados defensores en el

4 Desarrollamos esta clasificación sobre la base de lo que Hakan Tunç (2005) llamó la racionalidad militar, psicológica e ideológica detrás de la invasión a Irak. marxismo y el realismo, tiene la virtud de reconocer los factores estructurales que pudieron motivar la iniciativa norteamericana, aunque parecen correr el riesgo de exagerar la racionalidad de largo plazo de la superpotencia en un contexto fuertemente condicionado por los atentados del 11-S.

En el otro extremo, la interpretación interna prefiere poner mayor énfasis en el impacto de los atentados en la sociedad norteamericana y en la necesidad de buscar y capturar a los enemigos del pueblo americano: Bin Laden y luego Saddam Hussein. Esta explicación, más afín al pensamiento liberal, tiene la virtud de analizar mejor los factores coyunturales que explican el comportamiento de los Estados Unidos y el dramático giro en la política exterior de la primera administración Bush después del 11-S. Sin embargo esta visión pareciera algo endeble al insinuar que la actuación de la superpotencia fue una reacción espasmódica, carente de toda racionalidad ulterior. Interpretar el fenómeno en estos términos sería negar la importancia de otros actores y de un sistema condicionante, haciendo imposible cualquier análisis en el nivel internacional y relegándolo todo a un mero acto reflejo de Washington.

Una última explicación que denominaremos ideológica, pone mayor énfasis en la importancia de los neoconservadores durante el gobierno de Bush. Este grupo de intelectuales, cuya actitud ofensiva, idealista y patriótica resultó especialmente interesante al gobierno y a la opinión pública después de los 
Luis L. SCHENONI • Atando a Gulliver: los Estados débiles del mundo islámico...

atentados, habría tenido la influencia suficiente para reforzar la posición ofensiva de los norteamericanos en Afganistán y provocar la invasión de Irak. Desde este punto de vista, Estados Unidos no actuó por presiones internas ni por ansias de poder en el sistema internacional, sino porque en un mundo unipolar la amenaza de los weapon states $^{5}$ debía ser enfrentada de forma unilateral (Krauthammer 2003) y de una forma particular: implantando democracias por la fuerza.

Sin embargo, aun repasando estas explicaciones, nada responde una pregunta central: ¿Por qué Afganistán e Irak? Con relativa seguridad podríamos argumentar frente a la explicación geoestratégica que muchos otros Estados de la región tienen reservas de recursos naturales incluso más grandes que las afganas e iraquíes y que la posición estratégica de estos países no parece sustancialmente diferente de la de otros Estados de la región. También podríamos responder a los partidarios de la interpretación interna que muchos otros Estados podrían haber satisfecho las demandas del pueblo norteamericano, si no en Afganistán -aunque hoy sabemos que el Talibán no era el único aliado de $\mathrm{Al}$ Qaeda, sí era el más comprometido-, al menos sí claramente en el caso de Irak

5 Estados periféricos, aún no consolidados como Estado-nación, con fácil acceso a los ingresos de recursos naturales altamente redituables y posesión o perspectivas de posesión de armas de destrucción masiva (Krauthammer 1990:31).
¿Qué amenaza representaba Saddam Hussein que no presentaran otros líderes igualmente estigmatizados como Muhammar Al Qadaffi? Por último, la interpretación ideológica adolece de las mismas dificultades que las anteriores, pues la cantidad de weapon states en la región -potenciales destinatarios de la democracia-, difícilmente deja en claro qué es aquello que distingue a los efectivamente invadidos.

Así, por más que mucho de los ataques norteamericanos a Afganistán e Irak se explique desde la perspectiva de la política exterior de los Estados Unidos, pareciera que parte de la realidad podría ser comprendida mejor estudiando el comportamiento de los invadidos y de los que potencialmente pudieron serlo pero lograron evitarlo. Tomaremos para esta comparación los casos de Afganistán, Irak, Irán, Libia y Paquistán de 1989 a 2003.

\section{DE GRANDES AMIgOS A PEQUEÑOS ENEMIGOS:}

LAS RELACIONES DE AFGANistán E IRAK CON LOS Estados UNIDOS ENTRE I989 Y 200I/3

El año 1989 es en Afganistán el año de la retirada de las tropas soviéticas y de la victoria de la yihad que se consolidaría en 1992 con la caída del gobierno comunista de Kabul. La invasión de la Unión Soviética en 1979 y la posterior década de combate ininterrumpido para la liberación del país había dejado fuertes cambios en la sociedad afgana. 
Las milicias tribales organizadas por los «señores de la guerra» se multiplicaron varias veces, pasando del uso de rifles Enfield -que la corona británica había introducido a la región en 1857- al de misiles y fusiles de asalto modernos que perpetuarían la guerra civil por años. Afganistán se convirtió súbitamente en el hogar de varios millones de fanáticos islámicos, poblaciones repatriadas que diferían en sus composiciones étnicas y religiosas, generando un sinfín de partidos radicales en un país totalmente desmembrado. Finalmente, como es regla cuando una guerra se pelea en territorio propio, los afganos estaban desahuciados y necesitados de un caudal de asistencia internacional que nunca llegaría.

Durante la guerra contra la Unión Soviética, los aliados de los muyahideen ${ }^{6}$ habían sido muchos y muy dispares. Por un lado Paquistán, interesado en imponer un gobierno aliado en Kabul, aprovechó las circunstancias para incrementar exponencialmente la cantidad de madrassas en Peshawar ${ }^{7}$. Allí estudiaban el Corán y se entrenaban en el arte de la guerra las milicias pashtunas que también podrían servir para su conflicto con la India por Cachemira. Paquistán actuaba las veces de intermediario entre los Estados sunní-

6 En árabe «guerreros sagrados» $\mathrm{O}$ «aquellos que hacen la yihad». Nombre que adquirió fama para denominar a los rebeldes islámicos que lucharon contra los soviéticos. Capital de la North West Frontier Province (NWFP), desértica provincia paquistaní lindante con Afganistán. tas interesados en la victoria islámica -Arabia Saudita principalmente- y los rebeldes. El combustible para este incremento nunca antes visto de lo que luego se llamaría genéricamente «fundamentalismo islámico», estaba dado por los más de tres millones y medio de refugiados afganos en Paquistán y los dos millones que se dirigieron al norte de Irán.

Aunque la resistencia de los muyahideen al avance del Ejército Rojo dejó boquiabierto a muchos, no hay dudas de que la resistencia afgana venció gracias a la creciente ayuda que los Estados Unidos comenzaron a otorgar, aproximadamente a partir de 1985 , gracias al fuerte apoyo que la causa afgana obtuvo en el Congreso (Stork 1986). La masiva entrega de armamento vía Arabia Saudita y Paquistán terminó por desequilibrar la balanza en favor de los rebeldes. El ejemplo más claro y conocido de esta ayuda fue la entrega de misiles antiaéreos portátiles Stinger a los guerrilleros afganos, con los cuales derribaron un número nunca antes visto de los temidos helicópteros MI-24.

Después de la retirada soviética, el Partido Comunista de Afganistán seguiría controlando Kabul. La suerte del comunismo afgano se selló en enero de 1992, cuando los Estados Unidos y la Federación de Rusia acordaron detener el envío de ayuda militar a las partes. Dos meses más tarde los muyahideen llegarían al poder de la mano del líder tayico Rabbani.

Sin embargo, la guerra civil no terminaría. Los grupos rebeldes se 
Luis L. SCHENONI • Atando a Gulliver: los Estados débiles del mundo islámico...

contaban por centenares y las rencillas históricas por motivos étnicos, tribales y religiosos, sumadas al interés de cada uno de los líderes guerrilleros por obtener un puesto preeminente en la política nacional, terminó por dividir al país en distintos feudos controlados por «señores de la guerra». Ante esta situación, diversos actores regionales comenzaron a presionar para sacar provecho de la situación, mientras las Naciones Unidas encabezaban un desesperado intento por instaurar una paz duradera. La Federación de Rusia y la India se transformaron súbitamente en los principales socios comerciales y financieros de Afganistán. Irán, por su parte, estableció un asiduo vínculo aéreo que alcanzó los trece vuelos por día e incluso llegó a ofrecer entrenamiento en su territorio a los nuevos oficiales del gobierno de Rabbani. A cambio de este apoyo militar, Kabul entregó a los iraníes cinco misiles Stinger -tecnología que solo la OTAN y los afganos tenían para ese entonces.

Este banquete regional, producto de la fragmentación del Estado afgano, dejaba afuera a Islamabad e irritaba profundamente a Washington, quienes en última instancia decidieron alejarse de sus anteriores aliados. En 1994, un grupo de estudiantes del Corán -talibs- comenzó a mostrarse como una alternativa interesante para que el ejército y la inteligencia paquistaní (ISI) recuperaran sus vínculos con el vecino Afganistán. Un gobierno de esas características no tendría más concesiones para con los infieles rusos e iraníes -chiitas-, asegurando de algún modo la alianza con los países sunnitas como el mismo Paquistán y Arabia Saudita, aliados históricos de Estados Unidos en la región. Por otro lado, un grupo capaz de poner fin a la guerra civil e imponer un orden centralizado en Kabul era una opción que clarificaría el panorama, incluso para los norteamericanos (Lansford 2003: 143). Muy pronto el avance político y militar del Talibán resultó incontenible. Rabbani llamo a una shura-asamblea nacional-con el objeto de nombrar a un sucesor más apto, pero el Talibán atacó la asamblea y en septiembre de 1996 alcanzó el control de Kabul.

La guerra del Talibán contra los «señores de la guerra» y antiguos $m u$ yahideen continuó en el norte, donde el avance fue devastador e incluso pueblos enteros fueron masacrados ante la más mínima sospecha de colaboracionismo (Magnus 1998). En el resto del país se comenzaron a aplicar antiquísimas prácticas para el castigo a los delincuentes y rebeldes tales como el azote público, la lapidación de mujeres, las ejecuciones sumarias públicas y la amputación de miembros. Los nuevos decretos reflejaron la estricta aplicación de una concepción ortodoxa de la ley sharia que el mundo islámico no conocía. Proliferaron las medidas autoritarias, entre ellas la que establecía la longitud exacta que debía tener la barba, la publicación de una lista de nombres permitidos para los neonatos, la expulsión de todas las mujeres de las escuelas y su reclusión en el hogar, 
donde debían trabajar con las ventanas ennegrecidas para no poder ser vistas.

Toda esta inesperada situación -que a su vez podía verse por televisión en todo el mundo- terminó por sentenciar cualquier tipo de alianza que los Estados Unidos pretendieran con este grupo ya asentado en el poder. El mundo entero se conmovía ante las permanentes violaciones de los derechos humanos, que se sumaban a un notable incremento de las exportaciones de heroína desde Afganistán. Esta nueva situación se evidenció con claridad en noviembre de 1997 cuando Madeleine Albright, Secretaria de Estado norteamericana, declaró: «... somos contrarios a los Talibán debido a su oposición a los derechos humanos $y$ su vil tratamiento de las mujeres $y$ los niños, así como su enorme falta de respeto por la dignidad humana...» (Rashid 2001:108).

Mientras Hillary Clinton en persona encabezaba al movimiento feminista norteamericano, el gobierno de los Estados Unidos, a pedido de las Naciones Unidas -organización cuya permanencia en Afganistán se había convertido en una pesadilla-intentó un último acercamiento a los Talibán con el objeto de detener la violencia en el país. El entonces embajador ante las Naciones Unidas, Bill Richardson, fue recibido ostentosamente en Kabul -incluso el gobierno tuvo la consideración de suspender el espectáculo público de azotes y amputaciones que se daba en el estadio de fútbol de la capital- y el mismísimo Mulá Omar, enigmático líder del movimiento Talibán, recibió al funcionario.

Pocos meses después los afganos obligaron a todas las organizaciones no gubernamentales que operaban en Kabul y que brindaban ayuda a más de 600.000 personas, a trasladarse a un edificio derruido y sin servicios. Al poco tiempo, todas ellas abandonaron el país. Paralelamente, el Talibán ganaba el último bastión rebelde en el norte, la ciudad de Bamiyán, hogar de dos colosales figuras de Buda talladas en el siglo II de la era cristiana y lugar de peregrinación de las comunidades budistas de la India y China. Varias cadenas de televisión transmitieron la destrucción de estas reliquias de la humanidad, episodio que se transformó en el símbolo de la intolerancia del Talibán. Por otra parte, el refugio que recibía Al Qaeda en el país era públicamente declarado y los miembros más preeminentes de la organización terrorista fueron dotados de amplias funciones en el ejército y la administración. Todo esto condenó, como era de esperar, cualquier expectativa de reconciliación con occidente.

Hacia los comienzos del período que pretendemos analizar, Irak también estaba finalizando una década de conflicto que debilitó su ejército y su economía. En 1989, Irán e Irak sentaban las bases de la paz tras una larga guerra que los había enfrentado desde 1980 por el dominio del estrecho de Shatt Al-Arab.

La política norteamericana durante esta guerra, que comenzaba poco después de las grandes crisis del petróleo de 1973 
Luis L. SCHENONI • Atando a Gulliver: los Estados débiles del mundo islámico...

y 1979, tuvo como principal objetivo evitar un incremento de la capacidad productiva de Irán frente a otros actores regionales. El escenario más favorable para la estrategia norteamericana era una producción diversificada en la que ningún actor pudiera tener el monopolio del mineral. Por lo tanto, la ayuda a Irak no sería incondicional y aunque sería importante en algunos períodos, nunca alcanzaría los niveles suficientes como para dar a Saddam Hussein una victoria rápida o contundente ${ }^{8}$. Antes que eso, Washington se regocijaría prolongando su venganza por el escándalo internacional de la crisis de los rehenes y manteniendo a raya al régimen iraní.

Durante la guerra, gran parte de la ayuda extranjera a Irak provino de otros países de la región, que colaboraron ya sea mediante préstamos en dinero o en armas al gobierno de Hussein o mediante la aplicación de medidas económicas -como el aumento de las exportaciones de crudo- que causaban duros golpes a la enemiga economía iraní, alejada de toda ayuda económica. Uno de los actores más importantes en este sentido fue el histórico competidor de Irán por la hegemonía regional, Arabia Saudita, mientras que el otro gran soporte de Irak en la guerra fue Kuwait. Ambos Estados estaban fuertemente vinculados a los intereses de los Estados

8 Un breve esquema de la posición norteamericana durante la guerra puede encontrarse en: Oil and the Outcome of the Iran-Iraq War, en MERIP Reports $\mathrm{N}^{\mathrm{o}}$ 125/126, "The Strange War in the Gulf», Jul.-Sept. 1984, pp. 40-42.
Unidos en la región y compartían el credo sunnita y el discurso panarabista iraquí. Gracias a este apoyo exterior, el gobierno iraquí pudo modernizar su infraestructura militar, triplicar la maquinaria de guerra de las fuerzas armadas y quintuplicar sus efectivos en el frente (Stuglett 1990).

Al terminar la guerra con el armisticio de 1989, las concesiones entre las partes se limitaron a restituir el statu quo ante. Aunque las bajas fueron tres veces menores que las iraníes y las pérdidas económicas tampoco llegaban a alcanzar a las de su rival, Irak, por su menor población y pobre capacidad económica, distaba mucho de poder considerarse el ganador. Así las cosas, Hussein debía reintegrar a sus aliados los jugosos préstamos que le habían concedido durante el conflicto. La deuda con Arabia Saudita y Kuwait -los dos mayores acreedores- ascendía a veinte mil millones de dólares.

El gobierno iraquí comenzó a hacer uso de una estrategia de prestigio para dilatar los plazos de pago y lograr concesiones, recalcando el rol que había jugado el pueblo iraquí como guardián y héroe de la nación árabe. En este contexto, aunque Irak parecía priorizar sus deudas con occidente - pues mantenía una deuda no mucho menor con la Unión Soviética, los Estados europeos y en especial Estados Unidos comenzaron a desconfiar de la capacidad del régimen para honrar sus obligaciones?

9 Amplios sectores y representantes de la alta política norteamericana, entre ellos el 
Paralelamente las empresas occidentales comenzaron a presionar para que Irak redujera el rígido esquema burocrático del país a fin de disminuir los costos que la corrupción y las cargas tributarias suponían a los inversores, en especial a las petroleras. Esta actitud irritó a grandes sectores del Baath, dueños absolutos de la burocracia civil y militar del país.

En 1990 la situación iría de mal en peor. En un claro desafío a los intereses de Estados Unidos, Irak no solo no se mostraba dispuesto a pagar sus deudas sino que invertía cuantiosos recursos en la construcción de estatuas dedicadas a la victoria militar de Hussein y en la remodelación del palacio presidencial. En febrero, la prensa norteamericana comenzó a publicar escandalosos informes sobre la situación de los derechos humanos en Irak. Hussein respondió ordenando una campaña masiva de difamación dirigida contra el gobierno norteamericano y sus agentes económicos en la región. Un mes más tarde, un periodista británico fue ejecutado. Cuando las relaciones no parecían poder empeorar se produjo la increíble detención de algunos pasajeros iraquíes en el aeropuerto de Londres quienes, según las autoridades británicas, portaban piezas claves para el desarrollo de un arma nuclear. El tema de las armas

Vicepresidente Bush, hicieron grandes esfuerzos por evitar el descrédito de Irak en la banca occidental (Colhoun 1992). Pero todas estas iniciativas fueron perdiéndose hacia el final de la administración Reagan. de destrucción masiva pronto se ubicó al tope de la agenda ${ }^{10}$.

Así las cosas Irak, que aún debía soportar los constantes reclamos financieros de Kuwait, comenzó a injuriar a este pequeño vecino por no reconocer los esfuerzos del pueblo iraquí e introdujo en la relación bilateral el reclamo de una región del país sobre la cual Irak pretendía derechos históricos. De hecho, el norte de Kuwait no solo podría proveer a Irak de reservas petroleras sino incluso de un puerto de mayor calado. En agosto de 1990 Irak invadió Kuwait.

Kuwait había desarrollado un estrechísimo vínculo con los Estados Unidos en la década anterior, al punto de que gran parte de las inversiones norteamericanas en la región durante la guerra se concentraron en proteger la capacidad de exportación de petróleo del país (Stork 1987). La respuesta del líder indiscutido del nuevo orden unipolar y liberal fue legitimada por las Naciones Unidas y fue inmediata y contundente. En febrero de 1991 Irak perdía la Guerra del Golfo y reconocía más de una decena de resoluciones del Consejo de Seguridad que avasallaban su soberanía.

10 Uno de los episodios de la pasada guerra que daba a conocer los potenciales de destrucción masiva de Irak, fue el bombardeo con gas venenoso que se realizó sobre la población kurda del norte del país cuando estos grupos intentaron apoyar la causa iraní. El público conocimiento del uso de estas armas en contra de la población civil local dinamitó el crédito de Hussein todo el mundo. 
Luis L. SCHENONI • Atando a Gulliver: los Estados débiles del mundo islámico...

Hussein dedicaría los años venideros a reconstruir su base de poder interna frente a los kurdos y los chiítas que al norte y sur del país, respectivamente, amenazaban la hegemonía del Baath. Aprovechando la crisis interna y con el pretexto de proteger los derechos de estas minorías, Estados Unidos y Gran Bretaña recortaron la soberanía iraquí sobre su espacio aéreo, reduciéndola a una franja entre los paralelos 38 y 60 .

En 1993, reaccionando frente a las crecientes presiones de occidente, Hussein prohibió la visita de inspectores internacionales, provocando esporádicos bombardeos de las potencias occidentales. La crisis finalizaría con el ingreso de observadores y un informe del OIEA que disipaba cualquier sospecha sobre el desarrollo de la capacidad nuclear iraquí. Después de una nueva crisis en la frontera con Kuwait que no llegó a la etapa del combate, las Naciones Unidas aceptaron un levantamiento parcial del embargo que pesaba sobre Saddam, permitiéndole sacar provecho de sus exportaciones de petróleo -por fuera de los límites del programa Oil for Food-aunque solo fuera en una vigésima parte de las exportaciones iraquíes de cinco años antes. En adelante, una sucesión de crisis marcaron un sinuoso camino hacia el siglo XXI. Avances sobre los kurdos al norte del país, violaciones a las zonas de exclusión aérea y restricciones a los inspectores de las Naciones Unidas fueron algunas de las causas inmediatas de cada una de ellas. Sub- yacía sin embargo la realidad de un conflicto sin resolver ${ }^{11}$.

De más está decir que las relaciones con Estados Unidos no mejorarían en adelante. De hecho, en los años siguientes Irak perdió a muchos de sus aliados árabes y sunnítas en pos de una retórica mesiánica que condenaba a todos aquellos musulmanes que sirviesen a los intereses del «demonio» occidental.

Es importante recalcar aquí que Hussein no reaccionó frente a los sucesos del 11-S ni al ofensivo discurso norteamericano posterior. Como imbuido de un profundo rencor-o quizás acostumbrado al mal trato- no supo recomponer las relaciones a tiempo para salvaguardar su poder (Pauly \& Lansford 2005). Su terquedad lo convirtió en el peor enemigo del régimen que lideraba y que alcanzó un súbito final tras pocos meses de guerra durante el año 2003.

11 La más importante de estas crisis sucedió en 1998. Bagdad tenía pruebas fehacientes de que la información suministrada a las Naciones Unidas estaba siendo filtrada hacia agentes de la Mossad y la negativa a aceptar nuevas inspecciones fue utilizada como mecanismo de presión para que el embargo fuese levantado. La respuesta de los aliados fue desmesurada y cientos de civiles murieron en los barrios de la capital iraquí tras los más cruentos bombardeos que pesaron sobre el país desde la guerra. 
Atando a Gulliver:

LAS RELACIONES DE IRÁN, LIBIA Y PAQUistán CON LOS Estados UNIDOS DE I989 A 2004

El año 1989 es también el inicio de un nuevo período en Paquistán, donde tras más de una década de gobierno autoritario se instauraba la democracia.

El gobierno autoritario del General Zia había convertido a la religión en uno de los pilares de su gobierno, aunque a diferencia de su par iraní Jomeini, no pretendía utilizarla para subvertir el orden establecido, sino para legitimarlo mediante la inclusión de la burguesía piadosa y los religiosos en un sistema que seguiría estando bajo el control de los grupos militares y burócratas de siempre.

La invasión soviética de Afganistán fue un verdadero golpe de suerte para la recién estrenada dictadura militar, que comenzó a recibir grandes fondos de la alianza internacional que apoyaba a los mujabideen $n^{12}$. El dinero que se distribuía a través de los agentes de la Inter Services Inteligence (ISI) -inteligencia paquistaníserviría también para generar empleo y solventar los gastos de la administración y el ejército. Pero este nuevo rol tuvo consecuencias muy negativas para los

12 Resulta paradójico que los norteamericanos decretaran paralelamente el cese de toda ayuda económica a Paquistán con motivo de su renuencia a firmar el TNP y el acelerado desarrollo de su plan nuclear, situación por la cual los fondos debieron enviarse clandestinamente a través de la CIA u otros países árabes. paquistaníes desde el momento en que la burocracia y los militares fueron relacionándose con grupos fundamentalistas hasta incorporarlos a una verdadera red de vínculos informales. La creciente inmigración de voluntarios para la yihad contra los soviéticos, no solo transformó el orden demográfico de la población paquistaní, sino que fue también la puerta de entrada del terrorismo internacional con grupos como Al-Qaeda. A su vez, un estrecho vínculo fue creándose entre el clero islámico de los mullahs -encargados de las mezquitas, de los oficios religiosos y la educación en el Corán-y todos estos actores. Incluso los comerciantes musulmanes amasaron grandes fortunas en los primeros años de Zia, que conjugaron una gran entrada de dinero con un sinfín de actividades lucrativas vinculadas con la guerra en el país vecino. En este contexto, las autoridades paquistaníes declararon que -gracias a sus estrechos vínculos con China- el país había alcanzado el poderío nuclear, aunque no realizaría un ensayo hasta 1998.

La democratización se aceleraría tras la muerte de Zia en un accidente de aviación en agosto de $1988^{13}$. Las elecciones de ese mismo año dieron como vencedora a Benazir Bhutto, pero los militares impusieron al General

13 Algunas teorías conspirativas aseguran que el accidente fue provocado por la Mossad. Israel no veía conveniente el desarrollo de armas nucleares en un país islámico y tampoco toleraba la influencia que el gobierno de Paquistán ejercía sobre Washington con motivo de la yihad en Afganistán, para este entonces prácticamente victoriosa. 
Luis L. SCHENONI • Atando a Gulliver: los Estados débiles del mundo islámico...

Khan como Presidente y reaseguraron su permanencia en las esferas de poder hasta lograr una amnistía ${ }^{14}$. La vida de la democracia paquistaní fue desde entonces turbulenta y limitada por el ejército, el creciente rol del fundamentalismo y una importante corrupción. La alianza que aún hoy vincula al clero islámico con la oficialidad del ejército puso en difícil situación a los gobiernos democráticos.

Hacia 1991 se inició en Paquistán un acelerado proceso de inclusión de la ley sharia en la legislación. Ante la proliferación de los tribunales islámicos la sociedad se dividió entre la crítica liberal a las reformas y quienes las creían insuficientes y superficiales. Los partidos más extremistas de la coalición gobernante, como la Jammiat-I-Islami, utilizaron este clima para presionar a los gobiernos que se sucedieron durante toda esta década sin completar un solo mandato. En rigor de verdad, es posible que aun en ausencia de una oposición fuerte, estos gobiernos hubiesen sucumbido frente al público conocimiento de los flagrantes actos de corrupción que se cometieron en los años noventa. Pero el problema principal que debió enfrentar este conjunto de efímeros e inestables gobiernos democráticos fue el del crimen y los enfrentamientos civiles, favorecidos por la circulación de armas ligeras que ahora se conseguían en el mercado negro local. Las fuerzas de

14 Misma estrategia que utilizará Musharraf en la apertura democrática de 2008 hasta su dimisión. seguridad -cuando no estaban involucradas- poco podían hacer para detener la violencia que, de producirse, actuaba en favor del argumento autoritario y del regreso de los militares al poder.

Lo que más debe llamarnos la atención de la decadente democracia paquistaní, es la tensión que se estaba produciendo sobre el final del período entre un Estados Unidos cada vez más alejado y crítico del Talibán y un Paquistán cada vez más cercano a Kabul. Esta postura debió haber alarmado sustantivamente a los norteamericanos en una época en que el fundamentalismo comenzaba a quitarse el velo de freedom fighter perpetrando atentados en todo el mundo. Paquistán era para ese entonces el primer productor mundial de terroristas, así como su mayor receptor durante el éxodo talibán de 2001.

El encargado de dar la estocada final a la democracia sería Pervez Musharraf, quien perpetró el golpe de Estado tras la guerra de Kargil con la India que él mismo había comenzado ${ }^{15}$. La dictadura de Musharraf se consolidó

15 Musharraf tuvo un alto grado de responsabilidad en el planeamiento de las infiltraciones hacia Kargil, aun no contando con el mandato expreso de Nawaz Sharif y fue responsabilizado por el gobierno a causa de aquella imprudencia. Algunos meses más tarde, las tensiones entre el Jefe del Ejército y el Primer Ministro hicieron que este último, aprovechando la ausencia del primero, requiriera su renuncia. Pero la Corte Suprema y el ejército en conjunto se opusieron al gobierno civil. Sharif intentó cerrar el aeropuerto de Karachi para evitar la vuelta de Musharraf al país pero el ejército tomó el control del lugar y 
rápidamente; el flamante dictador legitimaría su gobierno a través de elecciones recién en el año 2002. El gobierno autoritario intentaría sostenerse en el poder en un difícil equilibrio entre las desbocadas fuerzas sociales que los cambios recientes habían desatado, cediendo muchas veces ante las varias presiones del fundamentalismo. Pero después de los atentados del 11-S Musharraf cambió radicalmente el discurso para oponerse al extremismo islámico, promovió controles a la fundación de madrassas y mezquitas provenientes del extranjero así como al ingreso de jóvenes estudiantes musulmanes al país. Estas políticas se desenvolvieron con las inevitables limitaciones y la hipocresía derivada de una larga connivencia entre las capas bajas de la administración y el ejército con grupos extremistas. Aun así, la situación costó a Musharraf gran parte de las amistades que había cultivado entre los sectores de la derecha islámica. La posición del gobierno frente a estos grupos empeoraría después de que Musharraf pronunciara discursos pro-israelíes con el objeto granjearse el apoyo occidental y la confianza norteamericana ${ }^{16}$.

posibilitó el aterrizaje del nuevo Presidente de Paquistán.

16 Es importante aclarar que gran parte de la bibliografía al respecto asevera que informalmente Musharraf no solo no actuó para desbaratar al fundamentalismo islámico, sino que incluso fortificó las relaciones entre el ejército, el clero y los grupos extremistas. Conocidos campos de entrenamiento terrorista siguieron funcio-
Las relaciones con Kabul después de la invasión norteamericana en 2001 también se llevaron en un doble plano: las altas esferas del gobierno y las instituciones visibles formalizaron una relación cordial con el gobierno de Karsai sustentado por los Estados Unidos, mientras que las capas bajas del ejército, el clero y la administración, junto con los partidos políticos islámicos, apoyaron subrepticiamente al Talibán, colaborando con la organización de la resistencia.

En lo que a la economía respecta, el gobierno de Musharraf comenzó sus días afrontando las sanciones que derivaron de las pruebas nucleares realizadas por Sharif en 1998, a las que se sumó la expulsión de la Commonwealh británica poco después de perpetrado el golpe de Estado ${ }^{17}$. Durante esos primeros años la deuda externa paquistaní aumentó considerablemente. Pero los sucesos del 11-S y la invasión de Afganistán devolvieron a Paquistán su importancia estratégica -se establecieron bases en su territorio- y resultaron en un gran aliciente para que las sanciones se levantaran e incluso se reanudara la ayuda económica que desde hacía más una década no se recibía.

Los desencuentros en la relación de los Estados Unidos con Irán deben rastrearse al menos hasta la Revolución

nando en diferentes lugares y con un nombre distinto (Abbas 2005).

17 Paquistán se convertía entonces en el primer y único Estado en la historia que era gobernado por un régimen militar en posesión de la bomba atómica. 
Luis L. SCHENONI • Atando a Gulliver: los Estados débiles del mundo islámico...

Islámica en 1979 y la crisis de los rehenes, probablemente el episodio más desagradable que la administración Carter debió enfrentar en materia de política exterior. Pero si esto es así, para 1989 no podemos decir de ningún modo que la relación hubiese mejorado. Durante la guerra con Irak, los norteamericanos no solo habían suministrado a Hussein asistencia económica y militar, sino que ingresaron de hecho en la guerra, hostilizando la armada iraní, bombardeando pozos petroleros y derribando una aeronave con 300 pasajeros civiles, acto aberrante por el cual no pagarían indemnización hasta 1995 y cuyo perpetrador fue condecorado por Reagan (Tarock 1996: 162).

Irán era entonces el segundo productor de petróleo de la región con casi la mitad de la producción saudí y más del doble de la iraquí, y la estrategia norteamericana de evitar un mayor control persa del recurso parecía justificar esta política ofensiva. Pero el enfrentamiento con la Revolución Islámica continuaría mediante operaciones encubiertas para subvencionar a grupos disidentes en Irán. Algunos de ellos eran grupos políticos de raigambre chiíta que cuestionaban el sistema de la revolución-monárquicos, republicanos y socialistas-, otros eran agentes externos con base en Irak y de raigambre sunníta -como el Muyahideen Khalg-. Como es sabido, hasta el día de hoy Estados Unidos apuesta firmemente por una estrategia de presión que termine por doblegar y subordinar a los iraníes ${ }^{18}$.

18 En relación con la posición regional de
El deterioro de las relaciones bilaterales llevó a que en el plano económico todos los avances comerciales llevados a cabo desde finalizada la guerra se cortaran en 1995 tras la Irán Sanctions Act, que al año siguiente incluyó a otros rogue states como Libia.

Después de una breve esperanza de reconciliación tras la victoria de Jatami en 1997, las relaciones volvieron a su habitual rispidez. Irán no fue la

Irán, Estados Unidos apoyó firmemente los reclamos que Arabia Saudita y los Emiratos Árabes Unidos realizaron para obtener la soberanía sobre las islas de Abu Musa y Tunb en el Golfo Pérsico. Mientras tanto, la diplomacia norteamericana objetó firmemente el crecimiento del presupuesto militar iraní que según datos de la CIA superaba los dos mil millones de dólares anuales destinados a la importación de armas (Milani 1994). Duras negociaciones se sucedieron entre Clinton y Yeltsin para intentar reducir el creciente rol de la Federación de Rusia en el rearme iraní, especialmente en el rubro de la tecnología nuclear; cooperación que hasta hace muy poco mantuvieron estas dos potencias. La cuestión nuclear ocupó un rol creciente en esta estrategia de contención, en especial a partir de la gestión de Ahmadinejad, aunque muchos autores aseguran desde los años noventa que Estados Unidos da por sentado que Irán conseguirá eventualmente la bomba atómica y que el Pentágono desde hace tiempo trabaja sobre este supuesto (Arkin 1995). En relación con otro actor regional de peso: Israel, Estados Unidos puso especial énfasis en vincular a Irán con el fundamentalismo islámico, en una interpretación maximalista de los vínculos que Teherán mantiene con Hezbollah y Hamas, entre otros grupos terroristas de origen chíta que operan en el Medio Oriente. 
excepción al avance del fundamentalismo en la región y las esperanzas de mayor secularización y acercamiento a occidente quedaron truncadas frente a la clara determinación por parte de Teherán de convertir al país en una potencia regional.

Hacia fines de los años noventa, fuertes presiones internas lideradas por el reformista Participation Front intentaron liberalizar las anquilosadas estructuras de la teocracia iraní. Tres reclamos fundamentales unen desde entonces a las más diversas alas de la oposición: la mayor accountability de los conservadores en el gobierno, la verdadera apertura democrática de acuerdo con los postulados de la corriente constitución y la mayor secularización del régimen en un futuro (Ehsani 2003). A pesar de la intensidad que estos reclamos alcanzaron después de las últimas elecciones, Irán supo mantener con relativo éxito su estabilidad interna y una sólida política exterior.

Después de las invasiones a Irak y Afganistán -que además de encorsetar al Estado persa le valieron algunas incursiones de los servicios de inteligencia norteamericanos-, los iraníes han sabido sacar provecho de la inestabilidad en torno suyo y ampliar su poder en la región.

Ya antes de entrar en el período que nos corresponde, las relaciones de Libia con occidente se encontraban por el suelo con motivo de la nacionalización de los yacimientos petroleros, el no reconocimiento de la existencia del Estado de Israel, la alineación con
Moscú -en rigor de verdad un producto de la ofensiva política norteamericana más que de la voluntad de Libia- y otros tantos asuntos.

Los roces comenzaron en el preciso momento en que Qadaffi llegó al poder (1969) pero alcanzaron a su máximo grado de tensión cuando Washington comenzó a mostrarse sistemática y abiertamente hostil hacia Trípoli durante los años ochenta ${ }^{19}$.

Durante esos años la CIA intentará orquestar un golpe contra el gobierno de Qadaffi, atentando incluso contra su vida (Hersh 1987). Esta ofensiva de los servicios de inteligencia, sin duda entre las más desfachatadas de la Guerra Fría, había provocado el temor a la respuesta libia, lo que contribuyó a escalar indefinidamente la confrontación (Zoubir 2002: 32).

Ya para ese entonces Libia no escapaba a la proliferación del terrorismo que se había producido en los últimos años en el mundo árabe (Kepel 2001). La expansión del fundamentalismo islámico tenía varios focos -hemos analizado el de la revolución iraní y el afgano/ paquistaní- pero en Libia encontró un importante caldo de cultivo en el con-

19 En 1981 cazas norteamericanos derribaron varios aviones libios de origen soviético en el Golfo de Sidra. En 1982 Reagan pidió a todos lo ciudadanos norteamericanos que se retiraran de Libia e impuso un embargo a las exportaciones de petróleo del país con lo cual las empresas fuertemente ligadas al mercado norteamericano debieron retirar sus instalaciones y expertos, lo que paralelamente disminuyó la capacidad exportadora del país árabe. 
Luis L. SCHENONI • Atando a Gulliver: los Estados débiles del mundo islámico...

texto de las relaciones árabe-israelíes que sucedieron a la guerra del Yom Kipur. Por entonces muchos grupos extremistas palestinos se entrenaban en campamentos libios, incluido el líder de la OLP, Yasser Arafat.

En 1986, un atentado contra algunos soldados estadounidenses en una discoteca de Berlín dio a los Estados Unidos la excusa perfecta para castigar desproporcionadamente a Libia. Los bombardeos sobre Trípoli y Benghazi de ese año son quizás el punto máximo de tensión al que llegaron las relaciones bilaterales, aunque nuestra historia no terminará allí. En 1988, un vuelo regular de la aerolínea norteamericana Panamerican Airlines explotó sobre la cuidad escocesa de Lockerbie muriendo 259 civiles. Inmediatamente los atentados fueron atribuidos a dos ciudadanos libios; para entonces, Libia parecía el epicentro del terrorismo mundial.

Entrando en el período que nos incumbe, el año 1989 comienza con la introducción del asunto de las armas químicas a esta conflictiva relación bilateral. Desde ya, las relaciones diplomáticas entre los dos Estados estaban suspendidas y en consonancia con sus anteriores procedimientos, el gobierno norteamericano acudió directamente al uso de la fuerza para desarmar una planta química en la ciudad de Rabta, bombardeada ese mismo año.

Por entonces un nuevo atentado sobre un vuelo comercial se produjo en Níger y la ofensiva internacional contra el terrorismo se concentró en el caso Lockerbie. Para 1991, algunos jueces norteamericanos y británicos habían solicitado la extradición de los dos ciudadanos libios sospechosos, a lo que el gobierno de Qadaffi contestó negativamente alegando las disposiciones de la Convención de Montreal de 1971. Un año más tarde el Consejo de Seguridad exigió a Libia la entrega de los sospechosos y en 1992, a causa del incumplimiento de la resolución, impuso severas sanciones al régimen magrebí ${ }^{20}$. Se pretendió incluso prohibir la compra de petróleo libio -medida que Estados Unidos mantenía desde principios de la administración Reagan-, pero los intereses de los países europeos pudieron más que la iniciativa estadounidense y la moción no fue aprobada.

En 1995 el Congreso norteamericano, en vista de la persistente negativa de Qadaffi a entregar a los terroristas, comenzó a tratar la posibilidad de penalizar a las empresas que tuvieran alguna inversión en Libia -tal como se había procedido con Irán- sin importar su nacionalidad ${ }^{21}$. En 1996 la tensión bilateral alcanzó un nuevo pico cuando funcionarios norteamericanos declararon que muy posiblemente nuevas

20 Las sanciones consistían en prohibiciones a dirigir vuelos al país, restricciones a la venta de piezas industriales -muchas veces fundamentales para la extracción de petróleo, principal industrial de Libia-, un embargo total de armas al país y un congelamiento de todos los fondos libios en el exterior.

21 Los decisores no ignoraban que tales medidas deteriorarían las relaciones con la Unión Europea y por ese motivo se postergó su aprobación. 
armas nucleares de precisión se utilizarían para destruir la planta química de Tarhuna en el desierto libio.

Pero con el tiempo Washington se quedaría solo en su cruzada contra Qadaffi. Conscientes de esta situación e intentando volver a encolumnar a sus aliados, Clinton firmó la Iran-Libya Sanctions Act provocando exactamente la reacción contraria. Ahora no solo los europeos, sino las propias petroleras norteamericanas interesadas en volver a Libia comenzaron a hacer lobby para que se levantaran las sanciones. En el contexto regional de la Jamaibiriya, resoluciones de la Liga Árabe y de la Unión Africana declararon que la medida norteamericana no solo era intolerable sino que en el futuro la propia resolución de las Naciones Unidas sería violada por los Estados partes.

Qadaffi, que desde hacía ya mucho tiempo tenía intenciones de mejorar sus relaciones con occidente, decidió aprovechar el apoyo político para reanudar las negociaciones promediando 1998. La base del acuerdo se encontraba en una Opinión Consultiva de la Corte Internacional de Justicia que recomendaba juzgar a los dos sospechosos libios del caso Lockerbie en Holanda, como territorio neutral. Una vez entregados los sospechosos al tribunal, la Unión Europea y el Secretario General de las Naciones Unidas, Kofi Annan, declararon cumplidas las exigencias que esta última organización había impuesto al país árabe.

En 1999 Estados Unidos y Libia retomaron sus relaciones diplomáticas después de 18 años de tensión. Las negociaciones para lograr que el Consejo de Seguridad levantara las sanciones llevaron a que Libia se comprometiera a combatir el terrorismo internacional expulsando a la organización $\mathrm{Abu} \mathrm{Ni}$ dal y apoyando el proceso de paz entre palestinos e israelíes. Sin embargo las sanciones no se levantaron hasta que Libia hubo cumplido con todas las exigencias $^{22}$. En todo caso, las relaciones se normalizaron muy suavemente a fin de no herir los sentimientos de los familiares de las víctimas del vuelo de Lockerbie ni los intereses israelíes o de otros grupos de presión en los Estados Unidos.

Llegado el crítico momento del 11-S y la invasión de Afganistán, Libia se encontraba inequívocamente en la lista de posibles blancos para una intervención norteamericana, junto con Irán, Irak, Siria, Sudán y quizás el Líbano (Zoubir 2002: 49). Todos estos países eran conocidos nidos de terroristas.

En marzo de 2003, mientras Estados Unidos desataba la guerra de Irak, equipos de negociadores del Reino Unido y de los Estados Unidos fueron recibidos en Trípoli para inspeccionar las instalaciones libias que, según se sospechaba, realizaban investigaciones

22 Entre otras, la expulsión del grupo Abu Nidal, la clausura de sus campos de entrenamiento, el establecimiento de mayores controles a la inmigración desde otros países árabes y la oposición a los grupos islámicos fundamentalistas del país. También ayudó al acercamiento el explícito cambio de postura de Arafat (siempre estrechamente ligado a Qadaffi) respecto del proceso de paz con Israel. 
Luis L. SCHENONI • Atando a Gulliver: los Estados débiles del mundo islámico...

biológicas, químicas y bacteriológicas con fines bélicos, así como los avances científicos en materia nuclear y misilística. En diciembre de ese año Libia declaraba terminados todos los programas que este grupo había objetado. En los meses siguientes Libia ratificó el Régimen de Control de Tecnología Misilística (MTCR), el Protocolo de Salvaguardias del OIEA, la Convención de Armas Químicas y su compromiso con el Tratado de no Proliferación Nuclear (TNP) y con la lucha internacional contra el terrorismo.

«Los líderes que abandonan la carrera por las armas quimicas, biológicas y nucleares y los medios para desarrollarlas encontrarán un camino abierto para mantener mejores relaciones con los Estados Unidos y otras naciones libres (...) Con el anuncio que boy ha realizado su líder, Libia ha comenzado el proceso para reunirse con la comunidad de naciones. El Coronel Qadaffi conoce el camino a seguir. Libia debería seguir los compromisos contraídos hoy. Libia debería también comprometerse profundamente con la guerra contra el terror...» ${ }^{23}$ Estas palabras de George W. Bush revelan claramente los nuevos progresos en la relación que se habían logrado gracias a las concesiones libias.

23 Discurso registrado en el 39 Weekly Comp. Pres. Doc. 1835, 1835-36 (Dec. 19, 2003) «Remarks on the Decision by Colonel Qadaffi of Libya to Disclose and Dismantle Weapons of Mass Destruction Programs». Departamento de Estado de los Estados Unidos de América.
Poco después se produciría un desbloqueo de fondos libios en el exterior con el objeto de que Libia indemnizase a las familias de las víctimas de los atentados de Lockerbie y Níger. Más de mil millones de dólares se destinaron inmediatamente a los pagos pendientes.

Hoy Libia no es considerada una amenaza por occidente. El escaso tiempo y las nítidas imágenes que permanecen en la memoria de muchos parecen ser los únicos obstáculos para considerarlo hoy un nuevo y buen amigo de Estados Unidos en la región.

\section{Midiendo LA ALINEACióN Y LAS CAPACIDADES DE LOS EsTADOS DÉBILES}

Para aplicar efectivamente el método comparado a este número acotado de cinco casos es preciso referirse a una igualdad inicial de condiciones -ceteris paribus-que posibilita la comparación (Sartori 1984: 268). Aludimos a un conjunto de supuestos que intentamos probar con lo antes expuesto y que básicamente pueden resumirse como sigue: a) todos estos Estados son débiles; b) con la posible excepción de Irak, todos ellos albergan grupos fundamentalistas/ terroristas en su territorio; c) ninguno fue democrático en el sentido liberal del término -salvo quizás Paquistán hasta 1998-; d) con la excepción de Paquistani todos poseían armas de destrucción masiva; e) todos tienen importantes reservas de petróleo o bien una importancia estratégica notable 
para su comercialización. Sin embargo, únicamente dos Estados de la región fueron invadidos en los inicios de la guerra contra el terror ${ }^{24}$.

Desde ya, estos supuestos son una simplificación de la realidad internacional a fin de generar un modelo y poder analizar algunas variables en particular. No queremos decir con esto que no existan diferencias de grado en cuanto a la presencia de las constantes expuestas, ni que no existan otras variables que podrían explicar el fenómeno. Como hemos aclarado oportunamente, este trabajo no pretende determinar las causas de las invasiones a Irak y Afganistán, sino aproximarse al estudio de una de sus posibles causas: las características de la política exterior de estos Estados. También por ello quedarán fuera del presente trabajo las consideraciones sobre los factores internos norteamericanos que determinaron que atacara a Afganistán e Irak y no a otros Estados. En suma, el análisis que sigue pone especial énfasis en el comportamiento y posibilidades de los invadidos, por encima de los incentivos del invasor.

Expuesto esto, es menester enfatizar la importancia que se ha dado a las cinco constantes expuestas, especialmente en la literatura que intenta explicar el estallido de estas guerras. En el pre-

4 Las excepciones expuestas no nos preocupan, no solo por ser escasas sino porque el hecho de que Irak no albergara grupos fundamentalistas o que Afganistán no posea yacimientos petrolíferos fortalece nuestra pregunta inicial ¿Por qué fueron invadidos esos Estados y no otros? sente trabajo dejamos de lado las explicaciones usuales, ponemos en duda su relación causal con el fenómeno y analizamos parsimoniosamente solo dos variables: el grado de alineación con Estados Unidos y las capacidades militares de cinco Estados de la región. Con esto estaremos intentando asir las fuentes de fuerza internas y fuentes de fuerza externas de estos actores (Handel 1981: 69) para conocer si su relación pudo determinar la suerte que corrieron frente a la expansión de la hegemonía norteamericana en su región.

Entendemos por "capacidades militares» aquellas propias de un Estado para hacer frente a un ataque armado exterior, medidas en relación con todos los demás Estados del sistema. Utilizaremos el índice de National Capabilities de la base de datos Correlates of War (COW) a los fines de medir esta variable (Singer y otros 1972).

La definición de "alineación» requiere un debate más profundo. En las relaciones internacionales generalmente se acepta, ya explícita o ya implícitamente, que la amistad internacional es relativa. Todos escuchamos alguna vez que "Inglaterra no tiene amigos permanentes ni enemigos permanentes, Inglaterra tiene intereses permanentes». La referencia obligada a la famosa frase de Lord Palmerston, un ejemplar exponente de la Realpolitik, es tan ilustrativa como la siguiente explicación de Waltz (1992: 243): «Desde las Guerras Napoleónicas muchos habian creído que los «republicanos» y los «cosacos» jamás 
Luis L. SCHENONI • Atando a Gulliver: los Estados débiles del mundo islámico...

se comprometerian, por no bablar de contraer matrimonio. El cortejo de Francia y Rusia, en el que cada uno de ellos se adaptó de algún modo al otro, fue consumado en la alianza de 1894, y produjeron asi la Triple Alianza cuando, primero Francia y luego Rusia, superaron las viejas animosidades contra Inglaterra, en 1904 y en 1907, respectivamente. Si las presiones son lo suficientemente intensas, un Estado puede pactar con casi cualquier otro.» En síntesis, las alianzas cambian y es por eso que configuran una variable en el presente trabajo y en muchos otros estudios.

Pero la discusión surge más bien en torno a qué tipo de variable es una alianza. Algunos enfoques postulan que la amistad internacional puede medirse mediante una distinción dicotómica entre aliados y no aliados -enemigos o neutrales-; otros enfoques críticos de esta postura (Wallace 1973) aseguran que la medición dicotómica no permite distinguir entre los muy diversos grados de alineamiento que pueden existir entre dos Estados. Quizás por las dificultades que se presentan a la hora de medir de forma continua esta variable, la mayor parte de la literatura utiliza una medición dicotómica para estos análisis. A pesar de esta extendida práctica, aplicaremos en el presente trabajo una medición continua de la variable, entendiendo por «alineación» o «amistad internacional»-términos que utilizaremos indistintamente- el grado de coordinación existente en la política exterior de dos Estados.
Existen diversas maneras de medir de forma continua la existencia de cierta alineación entre dos Estados: la coincidencia en votaciones dentro de órganos como la Asamblea General de las Naciones Unidas (Campbell 1971), la mutua participación en organismos internacionales (Wallace y Singer 1970) y el grado de interacción diplomática, son algunos de los indicadores más utilizados. Sin embargo, por las características propias de la relación entre Estados Unidos y el mundo musulmán, estos métodos no parecen reflejar la realidad. Los actores que intentamos analizar poseen culturas marcadamente diferentes e interactúan en contextos en que la seguridad ocupa el tope de la agenda. La importancia de que la seguridad domine constantemente la agenda bilateral -especialmente entre un Estado pequeño y una gran potencia- es tal, que para algunos autores cambia sustancialmente las características de las alianzas. Para Robert Keohane (1969: 302) "puede bien caracterizarse como una alianza de Al Capone, en la que permanecer como un aliado fiable no solo aporta protección contra terceros sino más bien contra la gran potencia en símisma, como pagando por la protección de un gangster de Capone en Chicago.» Naturalmente, los métodos más comunes para medir la alineación no contemplan esta situación excepcional, tan característica de los casos que nos toca analizar.

Por las razones expuestas, para medir el grado de alineación de cada 
uno de nuestros casos con Washington conformaremos un índice propio ${ }^{25}$.

Tomando como unidad de análisis el año/país y aplicando los índices de cada una de las variables a la historia comentada en las secciones anteriores, podemos ver cómo variaron en el período examinado la alineación con Estados Unidos y las capacidades militares propias de estos Estados (Gráficos 1 y 2 respectivamente).

25 Consideraremos como indicadores: a) ausencia de conflicto directo con los Estados Unidos ; b) ausencia de asistencia norteamericana a enemigos en un conflicto actual; c) ausencia de sanciones impuestas por Estados Unidos; d) existencia de relaciones diplomáticas con Estados Unidos; e) ausencia de una imagen negativa en el discurso del gobierno o en la prensa norteamericana f) explotación de recursos minerales abierta a capitales estadounidenses; g) fuertes lazos comerciales relativos con Estados Unidos; h) asistencia financiera de capitales o del gobierno de los Estados Unidos; i) asistencia militar de los Estados Unidos; j) presencia de bases militares estadounidenses en territorio propio; k) colaboración militar con los Estados Unidos; 1) participación relativa en tratados de desarme; $\mathrm{m}$ ) promoción de la lucha contra el narcotráfico, el terrorismo y otras amenazas a la seguridad en coordinación con los Estados Unidos. Conceptualmente podemos decir que los cinco primeros indicadores son requisito para una relación no conflictiva, mientras que los ocho restantes representan una mejora relativa de la relación hasta alcanzar el máximo grado de alineamiento históricamente posible en la región. Todos estos indicadores representan en la literatura disponible -especialmente aquella de origen realista- temas cruciales para evaluar las relaciones de los Estados Unidos con los Estados de la región (Crenshaw 2003).
Llegados a este punto, es menester analizar la relación existente entre estas variables. Como hemos visto, la crítica liberal supondría un comportamiento indirectamente proporcional de las dos variables (Conybeare 1994), situación que podríamos descartar, en particular si se considera el caso de Paquistán a partir de $1998^{26}$.

Más allá de las conclusiones que se desprenden del gráfico, el realismo posee un fundamento teórico para refutar la postura liberal frente a la relación alineación/capacidades militares. Esta premisa liberal -basada a su vez en la relación sustitutiva que existe en la teoría macroeconómica entre la recaudación impositiva y la emisión de deuda pública- es para el realismo una conclusión falaz. Aducir que estas variables se comportan como bienes sustitutos lleva en última instancia a suponer que los Estados dan igual valor a una y a otra, cuando en realidad las alianzas no suplen en absoluto -siquiera temporalmente- a la falta de capacidades militares. En palabras de Waltz (1992: 157) «Los estados procuran controlar aquello de lo que dependen, o disminuir el grado de dependencia..." y por lo tanto en relaciones internacionales, a diferencia de lo que pueda suceder en economía, dan un especial valor a

26 Aunque el análisis no sea estadísticamente significativo, cabe mencionar que en el presente análisis la correlación negativa $(-1$ a $-0,75)$ que aducen estas teorías liberales no solo no alcanzan estos valores, sino que incluso la correlación es levemente positiva $(0,17)$. 
Luis L. SCHENONI • Atando a Gulliver: los Estados débiles del mundo islámico...

\section{GRÁfico I}

Evolución De LA ALINEACión EN LOS CASOS EXAMINADOS, I989-2004, CON LOS Estados Unidos

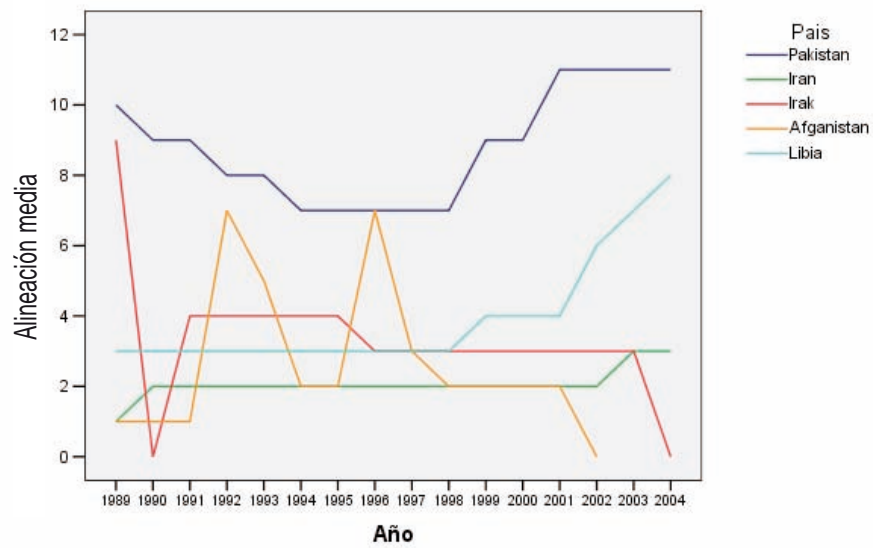

Fuente: elaboración propia sobre los datos del índice de alineación ad hoc.

\section{GRÁFICO 2}

EVOLUCIÓN DE LA CAPACIDAD MILITAR RELATIVA EN LOS CASOS EXAMINADOS

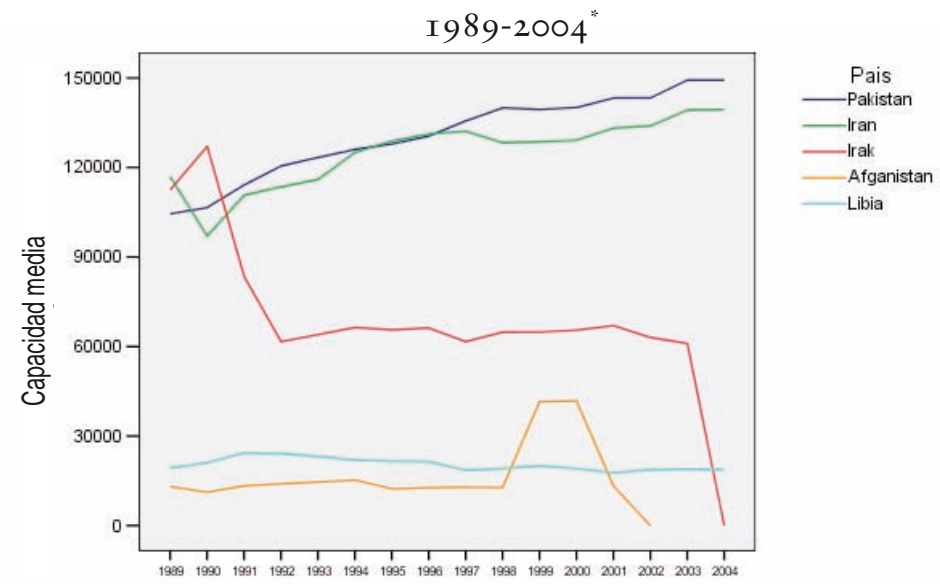

Año

Fuente de elaboración a partir de los datos de capacidades militares (COW).

Aunque hemos preferido no modificar este índice del COW en pos de una mayor claridad y fiabilidad, puede ser interesante para el lector conocer los datos de las importaciones militares -indicador más dinámico y de corto plazo- que los Estados en cuestión realizaron durante el período, en especial los aportados por el Stockholm International Peace Research Institute (SIPRI). Entre otras variaciones importantes se encuentra la inclusión del arma nuclear en el arsenal paquistaní en 1998 (Norris 2007), lo que sin dudas significaría un gran salto cualitativo, ausente en el gráfico. 
la autarquía medida en términos de Recapitulando, en los casos analicapacidades propias.

zados no existe una correlación clara

\section{GrÁFICO 3}

Posición Relativa DE LOS CASOS EXAMINADOS EN SEPTIEMBRE DE 200 I

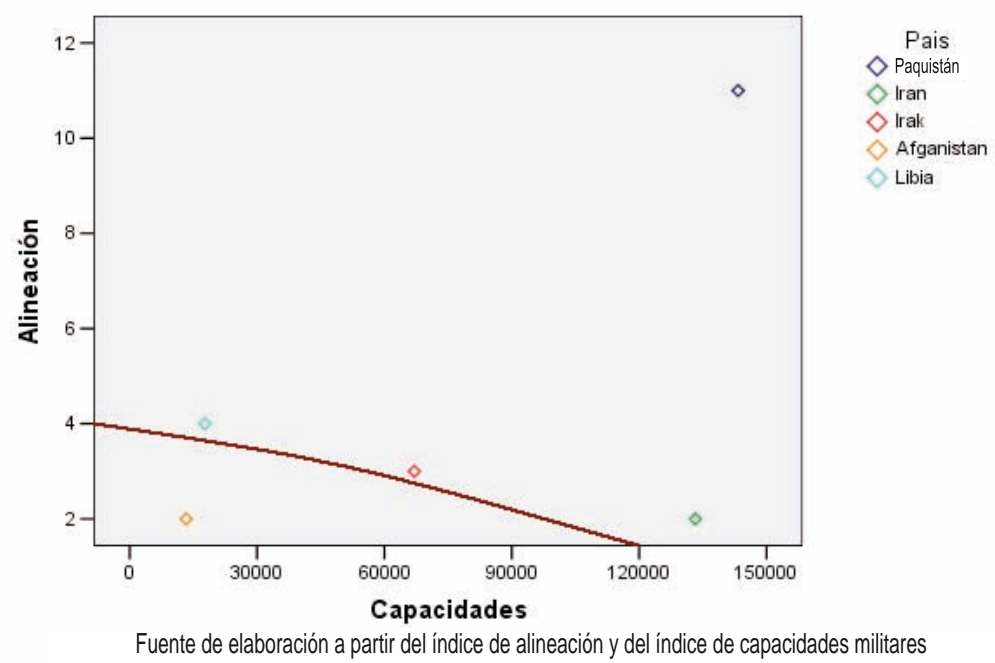

(COW). Datos al año 2001.

\section{GRÁFICO 4}

Posición ReLATIVA DE LOS CASOS EXAMINADOS EN FEBRERO DE 2003

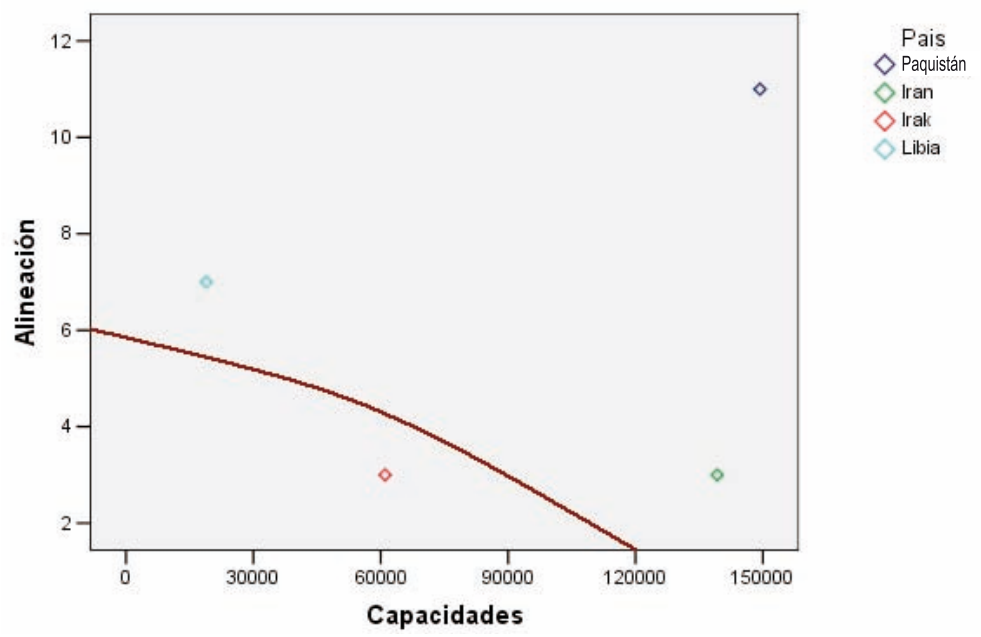

Fuente de elaboración propia a partir del índice de alineación y del índice de capacidades militares

(COW). Datos al año 2001. 
Luis L. SCHENONI • Atando a Gulliver: los Estados débiles del mundo islámico...

entre estas variables, pero puede sostenerse que los Estados que lograron incrementar su grado de alineación con Washington y paralelamente aumentaron su capacidad militar, se ubicaron en una posición relativa más sólida frente a los Estados Unidos (ver Gráficos 3 y 4).

Si imaginamos una función a modo de una curva descendente desde un número mínimo de alineación a un mínimo de capacidad militar, podemos ver cómo algunos casos quedan dispuestos de un lado y de otro de la línea. Tanto en el gráfico correspondiente a 2001 como en el correspondiente a 2003, observamos que los únicos países comprendidos en esta superficie son aquellos que resultaron efectivamente invadidos.

Paquistán representa el extremo no alcanzado por la curva, tanto por su alto grado de alineación como por su capacidad militar. Irán representa el caso de un Estado que logra escapar del rango de países susceptibles de invasión mediante el incremento de su capacidad militar.

El camino seguido por Libia y que tendría como mayores exponentes a Estados como los Emiratos Árabes Unidos, Jordania o Yemen, es en cambio el camino de quienes suplen su escasa capacidad militar con una alineación de mayor grado con los Estados Unidos.

Es interesante observar cómo Libia logró escapar de la difícil posición que ocupaba en 2001 por la vía de la alineación respondiendo automáticamente a las presiones que los Estados Unidos impusieron a la región en esos años.
Aunque no estén considerados en este breve estudio comparado, los casos de Siria y Sudán tienen características muy similares ${ }^{27}$. Estos dos ejemplos refutarían la hipótesis liberal de que en los Estados pequeños el nivel interno es determinante (Elman 1995), pues en estos casos el comportamiento es casi declaradamente una respuesta a las presiones sistémicas ${ }^{28}$.

27 Las presiones norteamericanas sobre Siria comenzaron con un embargo y una serie de requerimientos -sellar las fronteras con Irak, cesar la producción de armas no convencionales, retirar sus fuerzas del Líbano e ingresar en negociaciones con Israel- que a la sazón muchos analistas consideraron exagerados y absurdos. Algunos llegaron a declarar irónicamente que la política norteamericana hacia Siria "había sido formulada por Alicia en el país de las maravillas» o que «era Kafka» (Strindberg 2004). Sin embargo, para sorpresa de muchos, Siria cumplió en gran medida con estos requerimientos y logró borrar su nombre del «Eje del Mal».

Sudán fue en los años noventa desde refugio de Bin Laden y Al Qaeda hasta uno de los principales Estados en transformación hacia el fundamentalismo del África musulmana, adquiriendo nada menos que la talla de Libia en términos de instalación de campamentos terroristas y vínculos con el terrorismo internacional. Poco después de los atentados del 11-S, Al Bashir supo desvincularse rápidamente de los sectores más radicales -incluso envió al exilio al influyente político Turabi- para recomponer las relaciones bilaterales con Estados Unidos.

28 Para ser justos con el pensamiento liberal de Keohane y Nye (1998: 55), citado al comienzo de este trabajo, debemos decir que este caso de estudio evidentemente no es el más indicado para avalar la hipótesis liberal de que las instituciones internacio- 
El modelo que analiza el comportamiento de los Estados débiles en el presente trabajo tiene gran ventaja por su parsimonia y aplicabilidad al contexto de la unipolaridad. Basado en las premisas realistas permite admirar el comportamiento de un número de Estados relativamente débiles en interacción con las expectativas del hegemón.

La curva -que en adelante llamaremos «curva de expansión hegemónica»- representa en este modelo el grado de coacción que el hegemón está dispuesto a ejercer en el sistema para obtener una mayor cooperación para sus objetivos. Una mayor agresividad significa aquí mayor disposición a ejercer la coacción ${ }^{29}$. La curva puede describirse como sigue:

$$
f(x)=-k \cdot c^{2}+a
$$

nales ayudan a mejorar la posición relativa de los débiles. Si no estuvieron completamente al margen, las Naciones Unidas fueron plenamente condescendientes con el accionar norteamericano y no dieron oportunidad alguna, ni a los amenazados ni a los efectivamente invadidos.

La curva puede modificarse en diferentes sentidos según el comportamiento del Estado fuerte del sistema. En caso de que esté dispuesto a obtener cooperación por parte de los Estados más débiles, la variación de la función será un incremento en el valor de la ordenada al origen (la alineación mínima requerida) y una pendiente más negativa. Si por el contrario el interés del hegemón es desincentivar el armamentismo en los Estados más débiles del sistema, deberá incrementar el valor de la abscisa en el origen (capacidades máximas toleradas) y la curva adquirirá una pendiente menos negativa.
La ordenada al origen, «a», representa el grado de alineación mínimo requerido por el hegemón para que un Estado no sea considerado enemigo. Su valor es puramente una decisión del hegemón y se establece en relación con un Estado que hipotéticamente no tiene capacidad militar $(\mathrm{c}=0)$. La "c»" representa la capacidad militar posibles de los actores que configuran el sistema.

Por último, la pendiente de la curva, o «k», representa la tolerancia de la potencia en relación con las capacidades de los actores. El que la pendiente sea negativa significa que la superpotencia tolerará menores grados de cooperación o alineación de parte de actores más fuertes y viceversa.

Así, una pendiente $« \mathrm{k}=0$ » representa la intolereacia absoluta, es decir, la disposición a atacar a todo aquel que no cumpla con los requerimientos de alineación mínimos (a) sin importar su capacidad militar. Desde ya, la posibilidad de que una potencia hegemónica adquiera un $« k=0$ » solo es posible en el caso de que ni siquiera la suma del potencial del resto de los actores pueda vencerla. Se desprende de esto que cuanto más unipolar sea el sistema, la curva tenderá a una pendiente «k» más baja, mientras que cuanto más balanceado sea, el valor de «k» será mayor.

Es menester aclarar que en última instancia el valor de «k» siempre se basará en las percepciones que tenga el hegemón de su poder y del de los demás, dado que esta curva no existe en la realidad sino en los cálculos racionales de quienes formulan la política exterior 
Luis L. SCHENONI • Atando a Gulliver: los Estados débiles del mundo islámico...

basados en información no siempre disponible y altamente sensible, como es toda aquella relacionada con seguridad y defensa. Si comparamos los gráficos 3 y 4 se puede ver cómo el trazo de esta curva se traslada hacia arriba, lo que corresponde tanto a un aumento del valor de «a»-grado de colaboración requerido por el hegemón- que puede identificarse, al menos esa es nuestra intención, con el auge de la influencia del pensamiento neoconservador en el gobierno en 2003, grupo que percibió a los Estados Unidos como un actor relativamente más fuerte.

En el presente trabajo el modelo no se ha desarrollado de manera exhaustiva y las curvas solo cumplen una función meramente representativa. Sin embargo, no descartamos que futuros estudios puedan dar mayor contenido a los lineamientos básicos aquí establecidos.

\section{Conclusiones}

Dado que las relaciones internacionales han prestado relativamente poca atención a los Estados débiles, gran parte de los avances teóricos de la disciplina se han desarrollado en desconocimiento de estos actores, de sus comportamientos e implicancias. La primera intención de este trabajo es desempolvar el estudio de esta rama de la disciplina e intentar demostrar su relevancia para la comprensión de un acontecimiento tan relevante de la historia de las relaciones internacionales como son las guerras de Afganistán e Irak.
Las premisas realistas rescatadas del olvido de las últimas tres décadas nos han llevado a concluir que entre los muchos Estados débiles que pudieron haber sido atacados después del 11-S, solo Afganistán e Irak sufrieron una invasión debido en última instancia a dos razones fundamentales: su escasa alineación con los Estados Unidos y su vulnerabilidad militar. Con esto no queremos decir en absoluto que otros factores-como la posesión de armas de destrucción masiva, el amparo de células terroristas, las reservas de petróleo, etc.- no hayan influido en los decisores en Washington. Pero nuestra intención sí es recalcar que más allá de todos estos factores, cualquier Estado del mundo musulmán pudo evitar ser invadido manteniendo un determinado grado de alineación con los Estados Unidos y/o una fortaleza militar determinada. Analizando a modo de ejemplo la historia de Afganistán, Irak, Irán, Libia y Paquistán, llegamos a la conclusión de que, ceteris paribus, solo Afganistán e Irak se caracterizaron por una escasa alineación con los Estados Unidos y una notable vulnerabilidad militar a principios del siglo XXI.

Abstrayéndonos de los casos particulares que constituyen la base empírica de este análisis se ha pretendido configurar un modelo aplicable a otros casos en que exista un determinado número de Estados débiles en relación con una única potencia hegemónica. Dicho modelo se rige por los siguientes axiomas y normas: a) la potencia hegemónica tiene suficiente poder como para de- 
terminar con cierta discrecionalidad el grado de alineación mínimo que pretenderá y el poder militar máximo que tolerará en otros actores; b) los Estados débiles solo pueden evitar ser agredidos -o en otros términos, asegurar su supervivencia- por medio del incremento de su capacidad militar, del grado de alineación con el hegemón o de ambas variables a la vez; c) a un incremento de la agresividad del hegemón corresponderá un incremento global de los grados de alineación y de la capacidad militar de los otros actores; d) los Estados que no respondan de esta forma serán efectivamente agredidos.

Aplicando este modelo basado en la parsimonia de las premisas realistas a las relaciones entre los Estados Unidos y el mundo musulmán durante el período comprendido entre 1989 y 2001/3, la pretensión de este trabajo fue comprobar que las acciones u omisiones de los pequeños actores de la política internacional bajo estas premisas pueden moldear las actitudes de las grandes potencias hegemónicas, aunque bien no sea más que «atando a Gulliver», evitando ser atacados. Entendiendo los hechos posteriores al 11-S desde esta perspectiva aceptamos que, aun habiendo actuado los Estados Unidos bajo la influencia del pensamiento neoconservador, la estrategia norteamericana encontró sus fronteras en el realismo de los Estados débiles del mundo islámico.

\section{BibLIOgRAFÍA}

Abbas, H. (2005), Pakistan's Drift into Extremism: Allah, the Army and America's War on Terror, Nueva York, M.E. Sharpe. Arkin, W. (1995), «Iran and the Virtual Reality of US War Games", Middle East Report, no. 197 , pp. 10-13.

Bahadur, K. (2006), «Regional Implications of the Rise of Islamic Fundamentalism in Pakistan", Strategic Analysis, vol. 30, no. 1, pp. 7-29.

Campbell, A. (1971), «UN Voting and Alliance Cohesion", en: Millennium Journal of International Studies, vol. 1, no. 2, pp. 4-16.

Cardoso, F. H. y E. Faletto (1969), Dependencia y desarrollo en América Latina. Ensayo e interpretación sociológica, México, Siglo XXI Editores.

Colhoun, J. (1992), «How Bush Backed Iraq», Middle East Report, no. 176, pp. 35-37.

Conybeare, J. (1994), «Arms versus Alliances: The Capital Structure of Military Enterprise", The Journal of Conflict Resolution, vol. 38, no. 2, pp. 215-235.

Crenshaw, M. (2003), «Coercive Diplomacy and the Response to Terrorism", en: Art R. \& Cronin, M. (eds.) The United States and Coercive Diplomacy. Washington DC: United States Institute of Peace Press.

Desch, M. (1996), "War and Strong States: Peace and Weak States?», International Organization, vol. 50, no. 2, pp. 237-268.

Ehsani, K. (2003), «High Stakes on Iran», Middle East Report, no. 227, pp. 38-41.

Elman, M. (1995), «The Foreign Policies of Small States: Challenging Neorrealism in Its Own Backyard», British Journal of Political Science, vol. 25, no. 2, pp. 171-217.

Elton, D. (2000), The History of Iran, Westport, Greenwood Publishing Press.

Escudé, C. (1995),. El realismo de los estados débiles, Buenos Aires, Grupo Editor Latinoamericano.

Handel, M. (1981), Weak States in the International System, Londres, Frank Cass \& Co.

Hartman, A. (2002), «The Red Template: US Policy, en Soviet-Occupied Afghanistan», 
Luis L. SCHENONI • Atando a Gulliver: los Estados débiles del mundo islámico...

Third World Quarterly, vol. 23, no. 3, pp. 467-489.

Hersh, S. (1987), «Target Qadaffi», New York Times Magazine, 17 de febrero de 1987, p. 74.

Ingebritsen, C. (2006), Small States in International Relations, Seattle: University of Washington Press.

Jaffrelot, Ch. (2004), A History of Pakistan and Its Origins, Londres, Anthem Press.

Jaguaribe, H. (1979), «Autonomía periférica y hegemonía céntrica", Estudios Internacionales, no. 46, pp. 91-130.

Karsh, E. (1988), Neutrality and Small States, Londres, Routledge.

Keohane R. y J. Nye (1998), Poder e Interdependencia. La política mundial en transición, Buenos Aires, Grupo Editor Latinoamericano.

Keohane, R. (1969), «Lilliputians’ Dilemmas: Small States in International Politics», International Organization, vol. 23, no. 2, pp. 291-310.

Kepel, G. (2001), La Yihad: expansión y declive del islamismo, Barcelona, Ediciones Península.

Krauthammer, Ch. (1990), "The Unipolar Moment», Foreign Affairs, vol. 69, no. 5, pp. 23-33.

Krauthammer, Ch. (2003), «The Unipolar Moment Revisited", The National Interest, vol. 70, no. 1, pp. 5-17.

Lansford, T. (2003), A bitter harvest: US Foreign Policy and Afghanistan, Hampshire, Ashgate Publications.

Magnus, R. (1998), "Afghanistan in 1997: The War Moves North", Asian Survey, vol. 38, no. 2, pp. 109-115.

Milani, M. (1994), «Iran's Post-Cold War Policy in the Persian Gulf», International Journal, vol. 49, pp. 335-354.

Norris, R. (2007), «Pakistan Nuclear Forces», Bulletin of the Atomic Scientists, vol. 63, no. 3, pp. 71-74.

Pauly, R. y T. Lansford (2005), Strategic Preemption: US Foreign Policy and the Second Iraq War, Hampshire, Ashgate Publications.

Puig, J. C. (1980), Doctrinas internacionales y autonomía latinoamericana, Caracas,
Instituto de Altos Estudios de América Latina.

Rashid, A. (2001), Los Talibán, Barcelona, Ed. Península.

Rothstein, R. (1968), Alliances and Small Powers, Nueva York, Columbia University Press.

Sartori, J. (1984), La Política. Lógica y Método en las Ciencias Sociales, México, FCE.

Singer, J., S. Bremer, y J. Stuckey (1972), "Capability Distribution, Uncertainty, and Major Power War, 1820-1965.», en Russett B. (ed.) Peace, War and Numbers, Beverly Hills, Sage, pp. 19-48.

Singh Roy, M. (2006), «Pakistan's Strategies in Central Asia», Strategic Analysis, vol. 30, no. 4, pp. 798-833.

Sluglett, M. F. (1990),. "Iraq Since 1986: The Strengthening of Saddam», Middle East Report, no. 167, pp. 19-24.

Stork, J. (1986), "The CIA in Afghanistan: The Good War», Middle East Report, no. 141, pp. 12-13.

Stork, J. (1987), «Reagan Re-Flags the Gulf», Middle East Report, no. 148, pp. 2-5.

Strindberg, A. (2004), «Syria under Pressure», Journal of Palestine Studies, vol. 33, no. 4, pp. 53-69.

Tarock, A. (1996), «US-Iran relations: heading for confrontation?», Third World Quarterly, vol. 17, no. 1, pp. 149-167.

Tunç, H. (2005), «What was it all about after all? The causes of Iraq War», Contemporary Security Policy, vol. 26, no. 2, pp. 335-355.

Vandenbosch, A. (1964), «The Small States in International Politics and Organization», The Journal of Politics, vol. 26, no. 2, pp. 293-312.

Vandewalle, D. (2006), A History of Modern Libya, Londres, Cambridge University Press.

Vital, D. (1967), The Inequality of States: A Study of the Small Power in International Relations, Londres, Oxford University Press.

Wallace, M. (1973), «Alliance Polarization, Cross-Cutting, and internacional War, 1815-1964: A Measurement Procedure 
and Some Preliminary Evidence», The Journal of Conflict Resolution, vol. 17, no. 4, pp. 575-604.

Wallace, M. y D. Singer (1970), «International Governmental Organization in the Global System, 1815-1964», International Organization, vol. 24, no. 2, pp. 239-87.

Waltz, K. (1992), Teoría de la Política Internacional, Buenos Aires, Grupo Editor Latinoamericano.

Zoubir, Y. (2002), «Libya in US Foreign Policy: From Rogue State to Good Fel- low?», Third World Quarterly, vol. 23, no. 1, pp. 31-53.

\section{Fuentes on-line:}

The Stockholm International Peace Research Institute, disponible en:

www.sipri.org

The Correlates of War, disponible en: www. correlatesofwar.org 